\section{Pacific Northwest}

National Laboratory

Operated by Battelle for the

U.S. Department of Energy

\title{
Historical Sulfur Dioxide Emissions 1850-2000: Methods and Results
}

\author{
S.J. Smith \\ E. Conception \\ R. Andres* J. Lurz \\ * Department of Space Studies, University of North Dakota
}

January 2004

Prepared for the U.S. Department of Energy

under Contract DE-AC06-76RL01830

Joint Global Change Research Institute

8400 Baltimore Avenue

College Park, Maryland 20740 


\title{
DISCLAIMER
}

This report was prepared as an account of work sponsored by an agency of the United States Government. Neither the United States Government nor any agency thereof, nor Battelle Memorial Institute, nor any of their employees, makes any warranty, express or implied, or assumes any legal liability or responsibility for the accuracy, completeness, or usefulness of any information, apparatus, product, or process disclosed, or represents that its use would not infringe privately owned rights. Reference herein to any specific commercial product, process, or service by trade name, trademark, manufacturer, or otherwise does not necessarily constitute or imply its endorsement, recommendation, or favoring by the United States Government or any agency thereof, or Battelle Memorial Institute. The views and opinions of authors expressed herein do not necessarily state or reflect those of the United States Government or any agency thereof.

\section{PACIFIC NORTHWEST NATIONAL LABORATORY \\ operated by \\ BATTELLE \\ for the \\ UNITED STATES DEPARTMENT OF ENERGY}

under Contract DE-AC06-76RL01830

Printed in the United States of America

Available to DOE and DOE contractors from the

Office of Scientific and Technical Information,

P.O. Box 62, Oak Ridge, TN 37831-0062;

ph: (865) 576-8401

fax: (865) 576-5728

email: reports@adonis.osti.gov

\author{
Available to the public from the National Technical Information Service, \\ U.S. Department of Commerce, 5285 Port Royal Rd., Springfield, VA 22161 \\ ph: (800) 553-6847 \\ fax: (703) 605-6900 \\ email: orders@ntis.fedworld.gov \\ online ordering: http://www.ntis.gov/ordering.htm
}

This document was printed on recycled paper.

$(8 / 00)$ 
PNNL-14537

\title{
Historical Sulfur Dioxide Emissions 1850-2000: Methods and Results \\ PNNL Research Report
}

\author{
Steven J. Smith \\ Robert Andres* \\ Elvira Conception \\ Josh Lurz \\ * Department of Space Studies, University of North Dakota
}

January 2004

Prepared for the U.S. Department of Energy

under Contract DE-AC06-76RL01830

Joint Global Change Research Institute

8400 Baltimore Avenue

College Park, Maryland 20740 


\begin{abstract}
A global, self-consistent estimate of sulfur dioxide emissions over the last one and a half centuries was constructed by using a combination of bottom-up and best available inventory methods including all anthropogenic sources. We find that global sulfur dioxide emissions peaked about 1980 and have generally declined since this time. Emissions were extrapolated to a $1^{\circ} \times 1^{\circ}$ grid for the time period $1850-2000$ at annual resolution with two emission height levels and by season. Emissions were somewhat higher in the recent past in this new work as compared with other comprehensive estimates. This difference is largely due to our use of emissions factors that vary with time to account for sulfur removals from fossil fuels and industrial smelting processes.
\end{abstract}

\title{
1. INTRODUCTION
}

Sulfur is ubiquitous in the biosphere and often occurs in relatively high concentrations in fossil fuels, with coal and crude oil deposits commonly containing 1-2\% sulfur by weight. The widespread combustion of fossil fuels has, therefore, greatly increased sulfur emissions into the atmosphere, with the anthropogenic component now substantially greater than natural emissions on a global basis (Smith et al. 2001).

Anthropogenic emissions have resulted in greatly increased sulfur deposition and atmospheric sulfate loadings near most industrialized areas. Sulfate acid deposition can be detrimental to ecosystems, harming aquatic animals and plants, and damaging to a wide range of terrestrial plant life. Sulfur dioxide forms sulfate aerosols that are thought to have a significant effect on global and regional climate. Sulfate aerosols reflect sunlight into space and also act as condensation nuclei, which tend to make clouds more reflective and change their lifetimes. The radiative forcing change wrought by sulfate aerosols may be second only to that caused by carbon dioxide, albeit in the opposite direction (Shine et al. 1999; Ramaswamy et al 2001).

Historical reconstructions of sulfur dioxide emissions are necessary to access the past influence of sulfur dioxide on the earth system. Sulfur dioxide forms sulfate aerosols which alter the radiative balance of the atmosphere. Sulfur dioxide emissions are also the primary cause of anthropogenic acidification in many areas. The present reconstruction is intended for use in global environmental studies. Data is drawn from a variety of sources, as documented below, to produce the most accurate inventory possible. The emissions reconstruction presented here offers high accuracy by accounting for regions with emissions controls, has annual resolution, includes all anthropogenic sources, and provides global coverage.

This data set is an update and expansion of Smith et al (2001).

\section{METHODS}

This inventory was constructed by using a combination of bottom-up calculations and Best Available Inventories (BAI). All emissions, in principle, can be estimated using the equation:

$$
\text { Emissions }=\text { Emissions Factor } \times \text { Driver, }
$$

where the drivers depend on the emissions sector. In some cases, emissions in a region are considered known due to the construction of detailed regional emission inventories.

\author{
Coal Combustion \\ Oil Combustion \\ Natural Gas Processing \& \\ Combustion \\ Metal Smelting \\ Other Industrial Processes \\ Traditional Biomass Combustion \\ Land-Use and Land-Use Changes \\ Other \\ Ocean Bunker Fuels \\ Table $1-\mathrm{SO}_{2}$ emissions categories
}


Emissions can also be estimated using a mass-balance approach. In these cases the emissions factor can be calculated given an appropriate driver. The methods used to estimate emissions factors and drivers will be discussed below.

These emissions estimates were divided into nine categories, as shown in Table 1. ${ }^{1}$ These categories were selected on the basis of common driving forces available in long-term data sets. All emissions from coal combustion, for example, are scaled together over time. Emissions were estimated for 17 world regions plus ocean bunker fuels, as shown in Table 2.

\subsection{DRIVERS}

The emissions driver for each category is identified as the available quantity with which emissions will scale best with time. The emissions driver for fossil fuel emissions are fossil fuel consumption in each country. Coal and oil use is in terms of metric tones and natural gas consumption in volume units. Coal, oil, and gas consumption were taken from EIA data for 1980 - 2000 (EIA 2002). From 1950 to 1980 data were derived from UN energy statistics as used by Andres et al. (1999). Consumption data before 1950 for gas, oil, and coal are from Andres et al. (1999). Global consumption agrees well with the global production total of Etemad et al. (1991; as published through HYDE 2.0, 2002) for oil. Where necessary, figures were linearly extrapolated for countries with data gaps.

Fossil fuels used for ocean shipping, known as bunker fuels, were subtracted from fossil fuel use in each region. Ocean bunker data was taken from UN and annual EIA data from 1950 to 1999 (EIA 1996). Bunker fuel use was extrapolated for earlier years using the tonnage of registered ships from Mitchel (1998a,b,c). From 1914 to 1950 world shipping shifted from coal to oil using percentages reported in Fletcher (1997). Coal used for shipping purposes was taken to be 80,000 metric tones in 1915 (Fletcher 1997). Values for intermediate years were found by scaling scaled with shipping tonnage, assuming a 50\% improvement in efficiency from 1915 to $1940 .^{2}$

The primary driver for metal smelting emissions is smelter production. Figures are taken from USGS data (2002), USBM(1989), Schmitz (1979); and the HYDE database (2002). Massbalance calculations were used to estimate emissions as described below.

The driving forces for the other sulfur dioxide emissions categories are not as directly related to emissions than those for fossil fuels and smelting. Reconstructions of emissions estimates are, therefore, more speculative. The drivers for other industrial emissions, land-use, and traditional biofuels were approximated using the EDGAR-HYDE 1.3 historical estimates combined with data from other sources. In particular, the landuse change estimates from Ramankutty and Foley (1999) were used to scale past emissions from land-use change. These sources are generally a relatively small portion of total emissions.

\subsection{BASE-YEAR EMISSIONS}

For all sectors, an estimate of base-year emissions is necessary to calculate an emissions factor. The base-year for these calculations is 1990. In many cases, emissions inventory estimates were available for other years and, where available, these are used as described below. Extrapolation of emissions factors for other years is described in the next section.

USA
Canada
OECD90 Europe
Japan
Aus \& NZ
FSU
China/CPA
Middle East
Africa
Latin America
S\&E Asia
Eastern Europe
Korea
India
Argentina
Brazil
Mexico
Oceans (bunker fuels)
Table 2-World regions
used.


The source for base-year emissions depends on the sector and region. In general, base-year emissions were taken from Smith et al. (2001), updated as noted below. For most regions with emissions inventories, detailed sectoral break-downs were not available. As in Smith et al., estimates of the split between emissions sectors were made based on available data.

Sulfur dioxide emissions from metal smelting emissions were estimated using a mass balance approach. Metal smelting outputs for copper, zinc, lead, nickel, and aluminum were multiplied by emissions factors representing the sulfur content of metal ores. Emissions were estimated as the total sulfur content of all metal ores minus estimated sulfur removals (USGS 2002).

The sulfur emissions from metal smelting depend on the sulfur content of ores, processing techniques, and the amount of sulfur extraction. Estimates of the amount of metal processed and the amount of sulfur extracted are available (USGS 2002). Regional values for the sulfur content of ores are generally not available. Sulfur emissions also depend on processing techniques, for example, if sulfur-containing minerals associated with metal ores are separated out before smelting.

Emissions from metal smelting are, therefore, highly uncertain in the absence of regional inventories. Default values for the emissions factors were taken from AP 42 (USEPA 1996b). Estimates of metal smelting emissions are available for Canada, the Former Soviet Union, and Australia. Ore sulfur contents were adjusted to match these regional emissions estimates for 1990. We find that the sulfur content of ores in these regions are significantly higher than the AP 42 values. For Canada, the effective sulfur content of ore appears to have decreased significantly between 1980 and 1995 . $^{3}$

Emissions for other industrial processes are taken from country-level inventories where available. Where these are not available, values from EDGAR 3.2 inventory were used (Olivier and Berdowski, 2001). Traditional biomass and land-use emissions (deforestation, savannah burning, and agricultural waste burning) were also taken from EDGAR 3.2 for most regions. For Asian regions values for traditional biofuels were taken from Streets and Waldhoff (1998).

For India, we found significant differences between the emissions estimates sited above for traditional biofuels and oil-related emissions and the values estimated by Garg and Shukla (2002). The average of the two values was used for a base-year estimate in these two cases.

For ocean bunker fuels sulfur contents of 3\% for residual oil, $1 \%$ for fuel oil, and $1.1 \%$ for coal were assumed.

\subsection{EMISSIONS FACTORS OVER TIME}

For the 1990 base-year, emissions factors are calculated by dividing emissions by the appropriate driver. Using these emissions factors for past years, however, would underestimate emissions since emissions reduction measures have been put into place over recent decades. Most of the reductions in coal emissions have occurred in the United States, Canada, Europe, and Japan. Reductions in oil emissions have occurred more widely because sulfur removal during petroleum refining has been widely applied.

Inventory data exist for the United States and Europe (West and East) that can be used to calibrate total emissions over time. For Europe, emissions factors were adjusted to match the inventories of Mylona (1996) and EEA (2002). In particular, over the first half of the $20^{\text {th }}$ century, the emissions factor for coal was adjusted so that emissions matched the inventory of Mylona (1996) since during this time emissions were dominated by coal use. For Japan, 
emissions coefficients were adjusted to be consistent with the post-WWII emissions estimates of Fujita (1993).

With the exception of Japan, there were few controls for coal emissions previous to 1980. In order to match inventory values in 1980 the emissions coefficients for oil were adjusted in regions with sulfur standards in place, accounting for oil used in bunker fuels, subject to the global constraints on the sulfur contained in crude oil discussed below.

In the United States, emissions factors were initially adjusted to match the historical estimates of USEPA (1996a) and Gschwandtner et al. (1986). We, however, found that the historical estimates from Gschwandtner $e t$ al. resulted in emissions coefficients for petroleum emissions in the United States that were unrealistically low as compared to other regions. We increased the oil emissions coefficient for the United States in early periods to a more realistic level, consistent with an estimated aggregate sulfur content for United States petroleum production of $0.9 \%$.

Emissions from petroleum products can be more difficult to estimate since much of the emissions can come from a relatively small amount of products that contain a high sulfur content. Imports and exports of crude oil and petroleum products with varying sulfur contents make regional estimates difficult.

On a global level, however, one can estimate the total sulfur content of crude petroleum production and subtract reports of sulfur extraction (USGS 2002) to estimate global sulfur emissions. Historical time series of oil production (HYDE) exist at the country level. This leads to uncertainties due to possible shifts in country-average sulfur contents as relative production from different fields within a country changes with time. There is also uncertainty in the fraction of sulfur that is retained in petroleum products consumed for non-combustion uses. Approximately $6 \%$ of petroleum products are used for non-energy uses and we assume that an equal fraction of the sulfur in crude oil is in these products. Regional estimates, as in Smith et al. (2001), were updated with newer sulfur extraction data for 1990 adjusting for imports and exports of petroleum products.

We find that an increasing amount of the sulfur in petroleum products has been extracted in recent years. By the end of the 1990s approximately $40 \%$ of the sulfur in world crude petroleum was removed during the refining process.

This global mass balance approach for 1990 results in oil emissions that are about $3 \mathrm{TgS}$ more than the sum of regional emissions. This implies that either the global mass-balance oil emissions estimate is incorrect or that regional oil emissions are larger than estimated. One possibility is that a larger portion of the sulfur content of petroleum products is sequestered in tars and asphalts not combusted. Note that in several developing countries mass-balance estimates were used to estimate total emissions from petroleum products.

Over time the global petroleum sulfur mass balance estimate was generally somewhat higher than the inventory-based estimate. During the 1950's and 1960's the mass-balance estimate is 1$2 \mathrm{TgS}$ higher than our estimates. Some years in the 1980's show the opposite behavior, with the global mass-balance estimate indicating around 1 TgS less than the estimate. During the 1990's the difference declines to less than $1 \mathrm{TgS}$.

A more complete estimate of the historical sulfur content of petroleum production, along with estimates of sulfur in non-energy products, would be needed to further quantify any possible deficit in global emissions estimates. It appears possible that emissions from petroleum products has been somewhat underestimated in 1990 and at points in the past. 


\subsection{SEASONAL AND HEIGHT DISTRIBUTION}

Estimates were also produced of the distribution of sulfur emissions by height and season. Emissions vary by season primarily due to fuel used in buildings for heating. The seasonal signal is also affected by the summer peak in electricity production due to cooling demands. Due to a lack of constant global seasonal data, this was not included. Since the countries with large cooling demands are also reducing emissions from electric power systems this contribution is not considered further and likely does not cause a large seasonal shift in emissions for most regions. Estimating the seasonal emissions signal thus requires estimates of coal, oil, and biomass fuel that is used for heating buildings.

We also produced estimates of emissions in two height categories: below and above 100 meters. The high emissions category are those sources for which the combination of tall stacks and thermal buoyancy are sufficient to loft emissions to greater than 100 meters above ground level. For these estimates the fraction of fuel used in industry and for electric generation are needed.

Historical data from the IEA/OECD (1997) was used to estimate the fraction of coal and oil used in buildings, industries, and electric generation. Data are available for OECD (circa 1990) countries from 1960 and from 1970 for some developing countries. Where necessary, data were linearly extrapolated to fill gaps. Fuel used for electric generation was extrapolated to earlier years using electric generation data from Mitchel (1998a,b,c), EIA (2002), SSFC/SC (1983). The fraction of fuel used for industries and buildings was assumed to increase as fuel use for electricity decreases. The resulting fractions are consistent with the estimates of fuel used in buildings for England from 1840 to 1887 as reported by Stephen (2001).

Seasonal emissions estimates depend on the amount of fuel used in buildings multiplied by the fraction of that fuel used for heating. In the US for example, over $90 \%$ of the fuel oil used in

Emissions Category

\begin{tabular}{|l|l|}
\hline Electric Generation & Power Generation \\
\hline Industrial Energy Use & $\begin{array}{l}\text { Industrial Sector } \\
\text { Oil Production } \\
\text { Iron and Steel Production } \\
\text { Cement Production }\end{array}$ \\
\hline Buildings & $\begin{array}{l}\text { Residential Sector } \\
\text { Residential-Commercial Sector }\end{array}$ \\
\hline Other Surface Fuel Emissions & $\begin{array}{l}\text { Road Transportation } \\
\text { Land Transportation Non-Road } \\
\text { OTS } \\
\text { Industry (Biomass) } \\
\text { Power Generation (Biomass) } \\
\text { Charcoal Production (Biomass) }\end{array}$ \\
\hline Metal Smelting & Non-Ferrous \\
\hline Other Industrial Processes & $\begin{array}{l}\text { Chemicals Production } \\
\text { Pulp and Paper Production }\end{array}$ \\
\hline Land-Use & $\begin{array}{l}\text { Deforestation } \\
\text { Savanna Burning } \\
\text { Agricultural }\end{array}$ \\
\hline Ocean Shipping (Bunkers) & International Shipping \\
\hline
\end{tabular}

Table 3-Emissions are estimated by region, year, and height for each of the categories on the left. Emission were distributed within each region using the EDGAR emissions grids (Olivier and Berdowski, 2001) given at right. 
residential buildings is used for space heating (EIA 1997). The fraction of fuel used in other regions that is used for heating is scaled by heating demand. Heating demand is estimated by first calculating "heating degree months" as the amount the average temperature is below 45 degrees for a global $1^{\circ} \mathrm{X} 1^{\circ}$ grid derived from New et al. (1999). This is multiplied by the global population grid of $\mathrm{Li}$ (1996). The percentage of building fuel use that is dedicated to heating is set for each region using the total heating demand as a guide. Emissions from fuel used for heating is then distributed on a grid using the heating demand as a template for each region.

Emissions by height are estimated by assuming that all electric power emissions are from tall stacks. While this is probably not strictly true for all regions, and particularly for early electric power plants, global data on stack heights is not available. Where electric power emissions are the most significant, there is more likelihood that tall stacks are used, so the error involved in this assumption should be small. One half of the emissions from the industrial sector are assumed to be from tall stacks from 1900 forward (with this fraction declining linearly to zero from 1990 to 1850). The fraction of metal smelting emissions from tall stacks is assumed to increase linearly from zero in 1890 to $100 \%$ in 1950 .

\subsection{EMISSIONS GRIDDING}

Emissions were distributed into a $1^{\circ}$ by $1^{\circ}$ grid by height, season, and year. Emissions estimates by season, height, region and end-use sector were derived as discussed above. Emissions are scaled separately by region and height within eight categories as indicated in Table 3 . The emissions distribution within each category was derived from the1990 EDGAR 3.2 (Olivier and Berdowski, 2001) emissions grids shown. The distribution for each year was scaled for each of the eight categories shown in Table 3. In many categories several of the EDGAR base-year emissions sectors were combined because detailed emissions information over time was not estimated at that level. Emissions were distributed independently within each of the 17 regions in Table 2 plus ocean shipping.

The distribution grid for each category, except seasonal emissions, is created by summing all of a category's component EDGAR data and then scaling the emissions in each region and category to match our inventory estimate. All data except building emissions are assumed to be equally distributed among the four seasons. Seasonal building emissions were distributed within each region according to the heating demand per grid cell as described above.

The height distribution is determined by the assumptions for the fraction of emissions in each category that are emitted in tall stacks. The spatial distribution is identical for the high and low emissions in each category.

\section{RESULTS AND CONCLUSIONS}

We have presented here a reconstruction of anthropogenic sulfur dioxide emissions from 1850 2000 (Figure 1). This provides a global, self-consistent estimate over the last one and a half centuries. We find that global sulfur dioxide emissions peaked about 1980 and have generally declined since this time. Global emissions in 2000 are estimated to be over $10 \mathrm{TgS}$ lower than the peak value. Changes in fossil fuel use, increases in the amount of sulfur removals from oil and non-ferrous metals, and controls on coal-fired power plants have contributed to this decline.

While our results are qualitatively similar to previous reconstructions, we find some significant quantitative differences. Figure 1 also shows a comparison of the global emissions found in this work with those found from several other inventories and compilations. The emissions found 
here are similar to those reported by Öm et al.(1996) before 1980. This is largely since their compilation used the same historical emissions data for the United States and Europe as here (with exceptions noted above), thus resulting in similar global estimates. Subsequent to 1970, however, our annual resolution reveals significant inter-decadal changes in global emissions trends not seen in other reconstructions.

Our global estimate is significantly larger than either the Edgar-Hyde inventory (Van Aardenne et al. 2001) or the results of Lefohn et al. (1999). Both of these inventories used a "comprehensive" approach where emissions factors were applied consistently across regions and times. Van Aardenne et al. specify that emissions factors between 1970 and 1990 were interpolated to account for emissions controls. Lefohn et al. have assumed constant emissions factors over time, with some adjustment for shifts to low sulfur coal in the US and flue-gas desulfurization. Note that the Lefohn et al. estimate includes fossil combustion and metal smelting, but not emissions from traditional biofuels, industrial processes (other than smelting), or land-use and land-use change. These emissions, 3-4 TgS for the last few decades in our inventory, account for some, but not all, of the difference between the two inventories.

Lefohn et al. (1999) report emissions by fuel so we can also compare our estimates at this level. Our estimate of emissions from coal are consistently lower than the Lefohn et al. estimates. The difference is from 10-20\% from 1930-1980, and almost 50\% lower in 1850. Our emissions from $1880-1890$ for Europe, which dominates emissions at this time, match those of Mylona (1996). The most significant differences are for the last several decades. The Lefohn estimates for coal increase steadily from 1950 - 1990 whereas our emissions estimates rise significantly less over this period, presumably due to our accounting for emissions controls in Europe and other regions. The two estimates for emissions from petroleum products have a similar shape from 1955 through 1990, although our estimate increases faster from 1955 to the late 1970. A similar difference is seen for metal smelting. The two estimates are very similar in 1990 and 1945, but our estimate increases more and then declines. These differences in emissions by source are largely due to our use of emissions factors that change over time to account for sulfur removals (including our use of inventory data that take such changes into account).

Since similar data sources were used for fossil-fuel use, we conclude that differences in the assumed sulfur contents of fuel over time result in larger emissions in the years 1950-1980 in our estimates as compared to the EDGAR-HYDE and Lefohn et al. estimates. In particular, we have adjusted emissions factors to be consistent with both national inventories and global massbalance estimates for oil.

The sources of sulfur emissions have changed over time, with the dominant sources globally currently coal, petroleum products, and metal smelting, as shown in Figure 2. The contribution of oil to global sulfur emissions has increased significantly since 1950. Its significance relative to other sources peaked in the late 1970's and has decreased since then due to increasing sulfur removal from refined petroleum products. This trend has been has, however, been offset slightly by increases in use of residual oil for marine bunker fuels, whose sulfur content, and therefore emissions, remains uncertain.

As expected from previous work (Smith et al 2001), we find that there has also been a shift in the regional distribution of sulfur emissions, with an increasing proportion of emissions from Asia (Figure 3). Until the middle of the $20^{\text {th }}$ century, emissions were dominated by Europe and North America. Since that time, emissions from other regions, Asia in particular, have increased. 
Since the mid-1970's, an increasing fraction of global emissions have originated from Asia. Emissions from other regions (Africa, Middle-East, South America and Latin America) have also increased, but to a lesser extent.

In summary, we have found substantial changes in the sulfur dioxide emissions, particularly in recent decades. The shifts in source category are important to document in order to produce estimates of future emissions that are consistent with historical trends (Smith et al. 2001). The substantial geographical shifts in sulfur emissions seen in recent decades (Figure 3) are important to incorporate in biogeochemical modeling efforts. These shifts may have significant implications for historical reconstructions of anthropogenic climate change in particular. To aid in such studies, an annual grid of sulfur emissions from 1850-2000 has been produced and is available from the authors (ssmith@pnl.gov).

\section{ACKNOWLEDGEMENTS}

The authors would like to thank the numerous colleagues and institutions who have made data available through the web and through personal communication. A project of this sort could not have been possible without such generous assistance. We also thank Elaine Chapman for helpful comments.

\section{SUGGEGSTED REFERENCE}

Smith, S.J., Pitcher, H. and Wigley, T.M.L. (2001) "Global and regional anthropogenic sulfur dioxide emissions" Global and Planetary Change 29, 99-119, as updated in S.J. Smith, R. Andres, E. Conception and J. Lurz (2004) Sulfur Dioxide Emissions: 1850-2000 (JGCRI Report. PNNL-14537). 


\section{GRAPHS}

\section{Global Anthropogenic Sulfur Emissions}

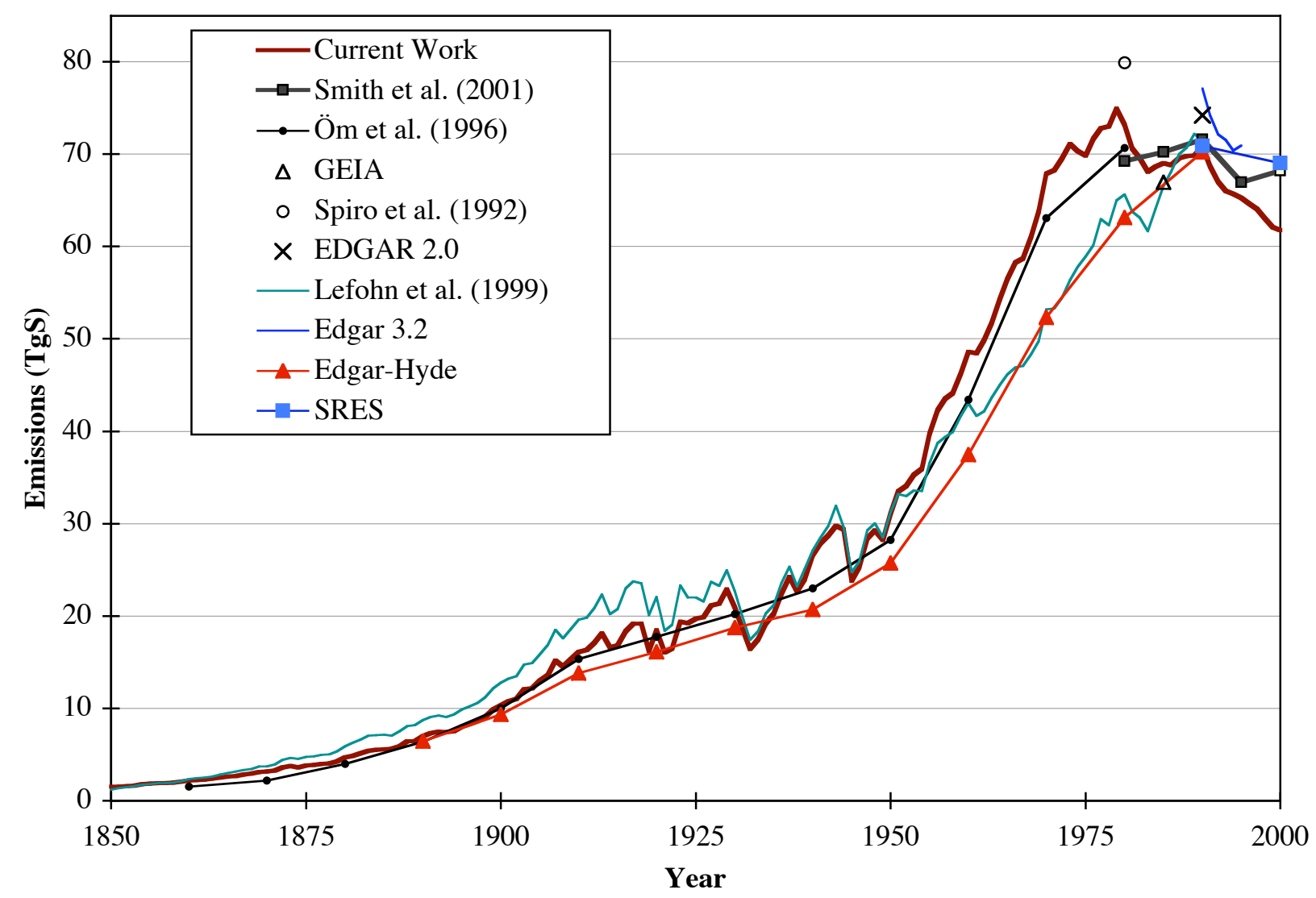

Figure 1-Global sulfur dioxide emissions from this study (thick line) and several other recent estimates (see text). Note that the Lefohn et al. estimate does not include all anthropogenic emissions sources. References not shown on the cart are: GEIA (Benkovitz et al.1996); EDGAR 2.0 (Olivier et al 1996); EDGAR 3.2 (Olivier and Berdowski, 2001); EDGAR-HYDE (Van Aardenne et al. 2001); and SRES (Nakicenovic and Swart 2000). 


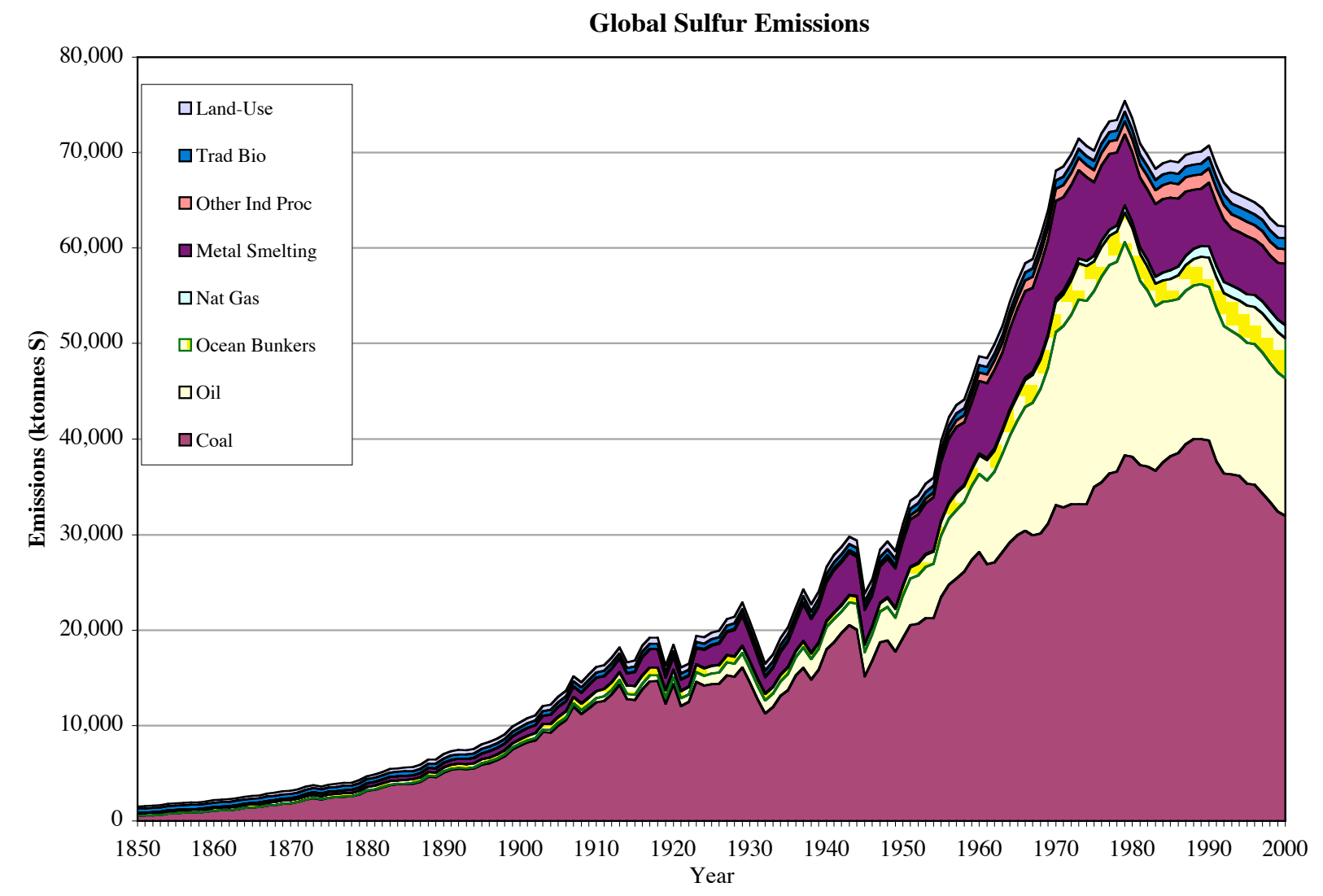

Figure 2-Global sulfur dioxide emissions by source. 


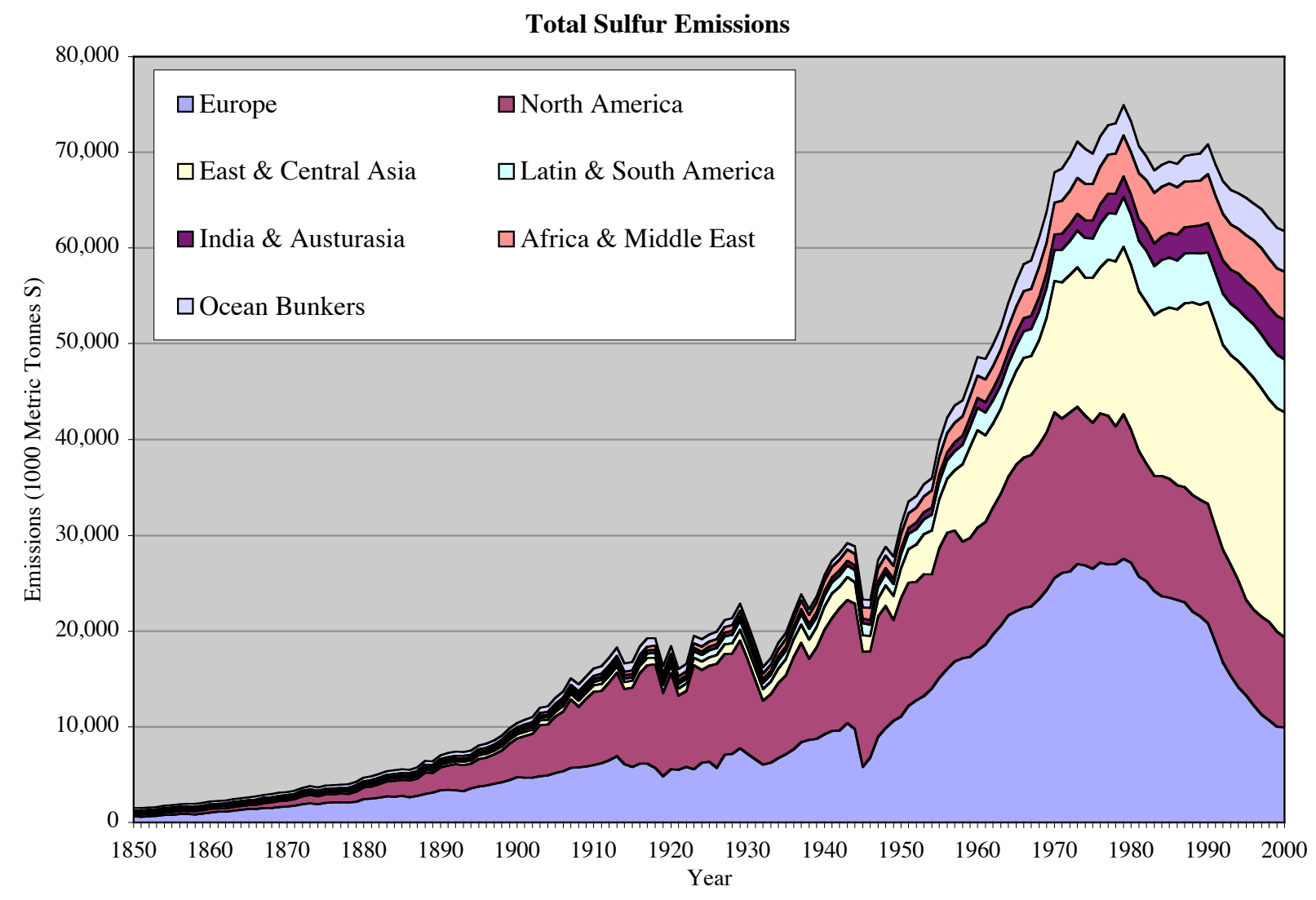

Figure 3-Global sulfur dioxide emissions by meta-region. 


\section{REFERENCES}

Andres RJ, Fielding DJ, Marland G, Boden TA, Kumar N (1999) Carbon dioxide emissions from fossil-fuel use, 1751-1950. Tellus 51, 759-765.

Benkovitz, C.M., M.T. Scholtz, J. Pacyna, L. Tarrason, J. Dignon, E.C. Voldner, P.A. Spiro, J.A. Logan and T.E. Graedel, Global gridded inventories of anthropogenic emissions of sulphur and nitrogen J. Geophys. Res. 101, pp. 29,239-29,253, 1996.

Energy Information Administration (EIA 1996), International Energy Annual 2002, Washington, D.C.. (Reports since 1993 available electronically at www.eia.doe.gov.)

Energy Information Administration (EIA 1997), Annual Energy Review 1996, Washington, D.C..

Energy Information Agency (EIA 2002), International Energy data, http://www.eia.doe.gov/international/.

Environment Canada (2002; http://www.ec.gc.ca/)

Etemad, B, P. Bairoch, J. Luciani and J.-C. Toutain, (1991). World energy production 1800 - 1985. Libraire Droz, Geneve. 272 pp.

European Environment Agency (EEA 2002).

Fletcher, M.E. (1997) "From coal to oil in British shipping" in Williams, David M. (ed.) The World of shipping (Aldershot, Hants, England; Brookfield, VT: Ashgate).

Fujita, S., Sanseiu kenkyu 100 nen no rekishi to sono hensen. J. Res. and Environ. 29, pp. 82-88, 1993.

Garg, A. and Shukla, P.R. (2002) Emissions Inventory of India. Tata McGraw-Hill, New Delhi.

Gschwandtner, G., K. Gschwandtner, K. Eldridge, C. Mann, D. Mobley (1986) "Historic emissions of sulfur and nitrogen oxides in the United States from 1900 to 1980" Journal of Air Pollution Control Association 36 pp. 139-149.

History Database of the Global Environment (HYDE 2002). http://arch.rivm.nl/env/int/hyde/index.html.

International Energy Agency/Organization for Economic Cooperation and Development (IEA/OECD), Energy Statistics and Balances (diskette service), International Energy Agency, Paris, 1997.

Lefohn, A.S., J.D. Husar, R.B. Husar (1999). "Estimating historical anthropogenic global sulfur emission patterns for the period 1850-1990" Atmos Environ 33 (21): 3435-3444.

Li, Yi-Fan (1996) "Global Population Distribution Database", A Report to the United Nations Environment Programme, under UNEP Sub-Project FP/1205-95-12, March 1996.

Mitchell, B.R. International historical statistics: Africa, Asia \& Oceania, 1750-1993. London: Macmillan Reference; New York: Stockton Press, 1998b.

Mitchell, B.R. International historical statistics: Europe, 1750-1993. London: Macmillan Reference; New York, N.Y.: Stockton Press, 1998c.

Mitchell, B.R. International historical statistics: The Americas 1750-1993. London: Macmillan Reference; New York: Stockton Press, 1998a.

Mylona, S., Sulphur dioxide emissions in Europe 1880-1991 and their effect on sulphur concentrations and depositions. Tellus 48B, pp. 662-689, 1996.

Nakicenovic, N. and R. Swart, eds. (2000) Special Report on Emissions Scenarios (Cambridge, U.K., Cambridge University Press).

New, M. G., Hulme, M. and Jones, P. D., Representing 20th century space-time climate variability. I: Development of a 1961-1990 mean monthly terrestrial climatology. J. Climate 12, 829-856, 1999.

Olivier, J.G.J. and J.J.M. Berdowski (2001) "Global emissions sources and sinks" In: Berdowski, J., Guicherit, R. and B.J. Heij (eds.) The Climate System, pp. 33-78 (A.A. Balkema Publishers/Swets \& Zeitlinger Publishers, Lisse, The Netherlands. ISBN 905809255 0). http://arch.rivm.nl/env/int/coredata/edgar/ 
Olivier, J.G.J., Bouwman, A.F., Van der Maas, C.W.M., Berdowski, J.J.M., Veldt, C., Bloos, J.P.J., Visschedijk, A.J.H., Zandveld, P.Y.J. and Haverlag, J.L. (1996). Description of EDGAR Version 2.0: A set of global emission inventories of greenhouse gases and ozone-depleting substances for all anthropogenic and most natural sources on a per country basis and on $1 \times 1$ degree grid. National Institute of Public Health and the Environment (RIVM) report no. 771060002 / TNO-MEP report no. R96/119.

Öm, G., U. Hansson and H. Rodhe, Historical worldwide emissions of anthropogenic sulfur: 1860-1985, Department of Meteorology, Stockholm University, Report CM-91, 1996.

Ramankutty, N., and J.A. Foley (1999). Estimating historical changes in global land cover: croplands from 1700 to 1992. Global Biogeochemical Cycles 13(4) 997-1027.

Schmitz, Christopher J. World non-ferrous metal production and prices, 1700-1976. London: Cass; Totowa, N.J.: Biblio Distribution Centre, 1979.

Smith, Steven J., Pitcher, H., and Wigley, T.M.L. (2001) Global and Regional Anthropogenic Sulfur Dioxide Emissions. Global and Planetary Change 29/1-2, pp 99-119.

Spiro, P.A., D.J. Jacob and J.A. Logan, Global inventory of sulfur emissions with a $1^{\circ} \times 1^{\circ}$ resolution. J. Geophys. Res. 97, pp. 6023-6036, 1992.

SSFC/SC (1983) Historical Statistics of Canada (Social Science Federation of Canada and Statistics Canada, electronic version. http://www.statcan.ca/english/freepub/11-516-XIE/sectiona/intro.htm)

Stephen, Mosley (2001) The chimney of the world: a history of smoke pollution in Victorian and Edwardian Manchester Cambridge : White Horse Press.

Streets D.G., and S. Waldhoff, Biofuel use in Asia and acidifying emissions, Energy 23, pp. 1029-1042, 1998.

U.S Geological Survey Minerals Information (USGS 2002) "Minerals Yearbook: Volume I -Metals and Minerals" Copper Statistics and Information. http://minerals.usgs.gov/minerals/pubs/commodity/myb/

U.S. Bureau of Mines (USBM, 1989). Minerals yearbook Zinc. (1989). U.S Dept. of the Interior [Pittsburgh, Pa].

U.S. Environmental Protection Agency (USEPA 1996a), National Air Pollutant Emission Trends, 1900 - 1995. EPA-454/R-96-007, Washington, D.C..

U.S. Environmental Protection Agency (USEPA), AP-42, Fifth Edition, Research Triangle Park, NC, 1996b.

Van Aardenne, J.A., Dentener, F.J., Olivier, J.G.J., Klein Goldewijk, C.G.M. and J. Lelieveld (2001) A 1 x 1 degree resolution dataset of historical anthropogenic trace gas emissions for the period 1890-1990. Global Biogeochemical Cycles, 15(4), 909-928.

\section{NOTES}

1 The "Other" category includes emissions that do not fall into any of the defined categories. Emissions in this category are very small (at present, only the US inventory is available at this level of detail) and this category is included for purpose of completeness.

Fletcher (1997) indicates that efficiencies increased over this period. Although the increase used here is somewhat arbitrary, this figure matches well the amount of coal used for bunker fuels in 1950 as reported in the 3 UN data.

Figures reported from Environment Canada (2002). This decline appears to be due to changes in processing practices, since the decline cannot be explained by reported sulfur removal figures (USGS 2002). This implies that sulfur in minerals associated with metal ores has been removed before the smelting processes. 